\title{
The Role of Fiscal Policy in The Inflation: VAR Analysis of Kazakhstan's Economy, 2005-2020
}

\section{Zhandos Ybrayev ( $\nabla$ zybrayev@nu.edu.kz )}

National Bank of Kazakhstan

\section{Research}

Keywords: Fiscal Policy, Inflation, VAR model, developing economy, Kazakhstan

Posted Date: June 1st, 2021

DOI: https://doi.org/10.21203/rs.3.rs-505243/v1

License: (c) (i) This work is licensed under a Creative Commons Attribution 4.0 International License. Read Full License 


\title{
The Role of Fiscal Policy in the Inflation: VAR analysis of Kazakhstan's economy, 2005-2020
}

\author{
Zhandos Ybrayev \\ National Bank of Kazakhstan \\ Senior Economist \\ Email: zybrayev@nu.edu.kz
}

\begin{abstract}
The paper analyzes the patterns of dynamic effects of fiscal policy to domestic inflation in the context of a small open economy. Using 4-variable (government spending, fiscal deficit, money stock (M2), and domestic inflation rate) vector autoregression model estimated with quarterly data for Kazakhstan's economy in the period of 2005Q1-2020Q1. We distinguish between government expenditure on consumption and investment. As a result, we find that a fiscal policy shock have certain positive effects on the inflation rate. In particular, social protection spending adds $1 \%$ to the inflation rate in the following four quarters, while the government capital purchases do not produce sizable effect on inflation dynamics even in the longer term horizons. Overall, for the fiscal policy to become inflation-neutral, we suggest several policy recommendations.
\end{abstract}

JEL Codes: E52, E58, E62,

Key Words: Fiscal Policy, Inflation, VAR model, developing economy, Kazakhstan 


\section{Introduction}

Are fiscal deficits inflationary in developing countries? What is the impact of different types of government expenditure (social protection versus infrastructure spending, for instance) on price stability? The "fiscal origins" of inflation have increasingly resurfaced in the macroeconomic analysis of emerging markets in the aftermath of the COVID-19 crisis and unprecedented government and central bank responses Benmelech and Tzur-Ilan (2020), Loayza and Pennings (2020), Stubbs et al. (2020). Developed by Sargent et al. (1981), a conventional model formed the ground to investigate the interaction between inflationary pressures and government budget imbalances. Authors argue that governments running persistent deficits sooner or later have to finance those deficits with money creation ("seigniorage"), therefore generating additional inflation. The issue is even more acute for countries with sovereign but not internationally accepted currencies, which experience institutional constraints and generally have both less fiscal and monetary policy spaces Epstein (2020). Such countries also suffer from less efficient tax collection, a substantial proportion of underemployment and hidden unemployment, high political uncertainty and limited access to external borrowing. The combination of these factors might increase the reliance on the inflation tax Alesina and Drazen (1989), Calvo and Végh (1999), Catao and Terrones (2005).

The well-established theoretical approach by Sargent et al. (1981) is based on the premise that monetary authority's control over inflation is limited. Particularly, if the fiscal authority "dominates" the monetary authority, then the fiscal authority independently chooses all current and future deficit levels. In this case, the monetary authority is constrained by the demand of government bonds and monetizes the deficit. When the monetary authority "dominates" the fiscal policy, the money supply is regulated autonomously and fiscal deficits would tend to be constrained and non-inflationary. Relatively recent approach emerged as the fiscal theory of the price level (henceforth, FTPL), which argues that the price level in an economy is determined in operational complementarity of both monetary and fiscal policies Cochrane (1998). As a result, when the fiscal authority adjusts the present value of its future surpluses, the price level will rise to lower the real value of debt. ${ }^{1}$ According to FTPL, fiscal agency is permitted to choose the surplus or deficit levels, not necessarily tied to fiscal solvency. Due to the exogenous character of fiscal actions, endogenous

\footnotetext{
${ }^{1}$ A critical discussion of the building blocks of the FTPL is provided in Canzoneri et al. (2001) and Buiter (2002)
} 
adjustment of the price level is required to achieve fiscal sustainability, which tends to make fiscal deficits inherently inflationary. Also, it is necessary to acknowledge the issue of non-linearity in the nexus of fiscal policy and inflation. Thus, Catao and Terrones (2005) model inflation through the inflation tax base and estimate the relationship as intrinsically dynamic. They found a strong positive association between deficits and inflation in high-inflation and developing countries, but not among low-inflation advanced economies.

In spite of a predominant theoretical view that fiscal deficits are inflationary, empirical validation of the argument is still mixed and does not produce a definitive conclusion on statistically significant connection between fiscal deficit and domestic inflation across a broad range of countries and inflation rates Lin and Chu (2013). For instance, studies on industrial and developed economies (Giannaros and Kolluri (1985), Protopapadakis and Siegel (1987),Barnhart and Darrat (1988)) have not reached a certain conclusion on the fiscal deficit-inflation link. At the same time, applied investigations on developing countries (De Haan and Zelhorst (1990) Metin (1998) Loungani and Swagel (2001) Domaç and Yücel (2005)), generally specify that the inflationary effect of deficit financing is insignificant, but they detect a significant causality of fiscal deficits on inflation in high-inflation countries.

This paper aims to empirically investigate the impact of fiscal policy on the inflation rate in developing countries using the case of Kazakhstan. Kazakhstan's economy underwent a significant shift around the mid 2000s and the entire 2010s, as the country has experienced windfall of oil revenues that likely have caused a greater procyclical in the fiscal policy. We hope to contribute to the analysis of the effects of fiscal policy by applying a Vector Autoregression approach to Kazakhstan's data during this period. Specifically, the paper distinguishes between social spending (current consumption), and public procurement, proxied by the manufacturing and industrial spending (capital consumption). Thus, we model a 4-variable VAR model, which includes the given type of government purchases under consideration (growth rates of total spending $(g)$, social protection spending $(s g)$ and manufacturing spending $(m g)$ ), fiscal government deficit as a share of GDP $(d)$, money stock growth rate $(M 2)$, and domestic inflation rate $(\pi)$. We collect a database of quarterly data for selected variables for the time period 2005Q1-2020Q1. We distinguish between government expenditure on consumption and investment. As a result, we find that a fiscal policy shock have certain positive effects on the inflation rate. In particular, social protection spending adds $1 \%$ to the inflation rate in the following four quarters, 
while the government capital purchases do not produce sizable effect on inflation dynamics even in the longer term horizons. Overall, for the fiscal policy to become inflation-neutral, we suggest several policy recommendations.

The rest of the paper is organized as follows. Section 2 presents a literature review on the fiscal policy effects on the domestic inflation, with a particular focus on developing countries. Section 3 explains our empirical approach and section 4 discusses the data. Section 5 provides the main results and the last section concludes.

\section{Literature Review}

Sargent et al. (1981) formally started the discussion on the relationship between fiscal deficits and inflation. They state that the budget deficit is jointly determined by bond sales to the public and seigniorage created by a monetary authority. Then, if a central bank conducts monetary policy independently by setting the growth rate of the money stock, fiscal authority faces a budget constraint, and fiscal deficits do not lead to inflation. On the other hand, If the monetary regulator cannot control its policy objectives, fiscal deficits are inflationary. In a more recent attempt to tackle this issue, building on a theoretical model, Catao and Terrones (2005) argue that sustained fiscal deficits might cause inflation through money creation, and equilibrium inflation is related to the fiscal deficit scaled by the stock of narrow money (instead of GDP, for instance), which also represents the inflation tax base. Thus, inflation is proportional to the product of the deficit-to-GDP and the GDP-to-narrow money ratios. Given a change in the deficit-to-GDP, an economy at a higher inflation level would be more strongly impacted by an increase in the deficit, because inflation tax base would typically be smaller. Also, the relation between the deficit and inflation is dynamic because the allocation of seignorage is intertemporal by borrowing, while fiscal policy largely determines the present value for the monetary accommodation of financing government bonds.

Another large strand of literature on the relation between fiscal deficit and inflation is the fiscal theory of the price level, that claims that the price level can be determined by the fiscal policy - Leeper (1991), Sims (1994), Woodford (1994), Woodford (1995), Woodford (2001), Cochrane (2001), Cochrane (2005), Leeper and Yun (2006). In a non-Ricardian model, both fiscal and monetary policies are exogenously determined by the government. In that manner, when the government adjusts the present value 
of its future primary balances, the price level will rise to lower the real value of the debt. Therefore, fiscal policy is directly linked to the price level through the present value budget constraint. Elmendorf and Mankiw (1999) find that an increase in debt has a positive wealth effect on households, and the aggregate demand will raise, which also will cause the inflation to rise.

Empirical investigations on the link between fiscal deficits and inflation is somewhat extensive. Giannaros and Kolluri (1985) studied data of 10 industrial countries from 1950 to 1981 and found that the impact of fiscal deficits on money supply and inflation is not significant. Protopapadakis and Siegel (1987) investigate the debt-money and the debt-inflation connections for 10 major advanced countries between the period of 1952-1987, and conclude that the association between debt growth and inflation is extremely weak. Barnhart and Darrat (1988) tested causality between fiscal deficits and money growth across seven advanced economies from 1960 to 1984, and rejected the hypothesis that the deficit Granger causes an increase in money growth.

Regarding the experience of developing countries, De Haan and Zelhorst (1990) examined 17 developing countries from 1961 to 1985 found that deficits are correlated to inflation during acute inflation periods. In a case study, Metin (1998) discovered that deficits lead directly to inflation in Turkey during the period of 1954-1986. At the same time, Loungani and Swagel (2001) discovered that the fiscal balance weakly correlates to inflation in 53 developing countries from 1964 to 1998, but the correlation becomes stronger in economies with higher inflation rate. Also, they showed a non-linear relationship between fiscal deficits and inflation, and that the influence of deficits on inflation is significant when the deficit-to-GDP ratio is above 5\%. Domaç and Yücel (2005) found 15 emerging market economies from 1980 to 2001 by pooled probit estimation and explore that government deficits are a significantly positive contributor of high inflation.

In addition, a number of papers have utilized both the time and cross-sectional dimension of data. Click (1998) using cross-country data of 90 economies from 1971 till 1990, found that domestic debt is not a determinant of seigniorage. Cottarelli et al. (1998) explored data of 47 countries from 1993 to 1996 and came to conclusion that fiscal policy play a considerable role in inflation. In addition, the link between past inflation and current inflation is persistent and dynamic. Fischer et al. (2002) analyzed the relationship between inflation, money growth, seigniorage and fiscal deficits on a large data set containing 94 countries during 1960-1995. Their cross-sectional result 
indicates that fiscal deficits are significantly positive correlated with seigniorage and inflation. Moreover, authors noted that in countries with high average inflation, fiscal deficits have a substantial impact on seignorage and inflation. Also, fiscal deficits are positively related to inflation during high-inflation period.

Catao and Terrones (2005) gathered a dataset from 107 countries over the period of 1960-2001, and apply the pooled mean group estimation to examine the short-and long-run impacts of deficits on inflation. They argue that the inflationary effect of deficits to inflation depends on the financial depth of a country, the inflation tax bases and the credibility of monetary authorities. Thus, fiscal deficits are inflationary in emerging market economies and high-inflation countries, but not in low-inflation and developed countries. Kwon et al. (2009) investigated the debt-inflation nexus on a panel of 71 countries, and found that debt growth is strongly inflationary in indebted developing countries, and less so in other developing economies. Lin and Chu (2013) examined the deficit-inflation connection in 91 countries from 1960 to 2006. Authors show the fiscal deficit has a strong influence on inflation in high-inflation episodes, and has a weak impact in low-inflation periods. Therefore, fiscal consolidation would be more effective in stabilization of prices in the environment of higher inflation.

In this paper, we use a VAR model that is supposed to catch the macroeconomic effects of increasingly procyclical-leaning fiscal policy following an extensive exploitation of natural resources. The main contribution of this paper is to conduct a quantitative analysis of government spending on domestic inflation in the context of a small open economy using the case of Kazakhstan, where a significant portion of exports and fiscal revenues are related to the oil sector. In addition, we specifically disaggregate government consumption between the cash-based social provision spending (current expenditure), and potentially employment-creating manufacturing public investment (capital expenditure). Thus, the income consequences in response to fiscal shocks produce differential responses to the price level, which generates practical policy recommendations for developing countries.

\section{Methodology}

\subsection{VAR analysis}

A vector autoregression (VAR) is a linear model in which each variable is explained by its own lagged values and the past and/or current values of other independent 
variables. Building on the seminal work of Sims (1980), they have been broadly used as a macro-econometric tool to investigate dynamic interactions in various time series. In general, VAR analysis begins with a selection of variables suggested by the theoretical model and then regressing each obtained variable on its own lagged values and the lagged values of the other variables in the system. The resulting estimates from the reduced form model can be used to track the effect of a shock to one of the variables. At the same time, these dynamic response functions (impulse responses) cannot detect the causal direction because the variables are likely to be correlated with each other, and we therefore cannot expect the shocks to be contemporaneously uncorrelated. Thus, a shock to one of the variables would also have a contemporaneous impact on some other variables through its own error term. Hence, to generate economically meaningful impulse response function one should use orthogonal shocks, where each shock is contemporaneously uncorrelated with every other shock.

Formally, we can specify our dynamic macro-econometric model in the following way:

$$
A X_{t}=A_{0}+A_{1} X_{t-1}+\ldots+A_{p} X_{t-p}+e_{t}
$$

where $X_{t}=\left[r g_{t}, d b_{t}, m 2_{t}, \pi_{t}\right]^{\prime}$ is a $4 \times 1$ vector of four variables - the growth rate of government spending (social spending and manufacturing spending), the deficit to GDP ratio, the growth rate of money stock, and annualized quarterly inflation rate. $A$ is the matrix of contemporaneous relations between the variables. $A_{t}$ is the matrix of relations between current values and lagged values, and $e_{t}$ are structural error shocks. Also, together with the linearity assumption and time-invariance of the coefficients, we assume that $\sum_{e}=E\left(e_{t} e_{t}^{\prime}\right)=I$ and $E\left(e_{s}, e_{t}^{\prime}\right)=0, \forall s \neq t$. Given the endogeneity of the regressors, we cannot directly estimate this structural model. Instead, we estimate the reduced form model, which is given by:

$$
X_{t}=B_{0}+B_{1} X_{t-1}+\ldots+B_{p} X_{t-p}+u_{t}
$$

The reduced form errors are not contemporaneously uncorrelated, $\sum_{u}=E\left(u_{t} u_{t}^{\prime}\right)=$ $A^{-1} A^{-1^{\prime}}$, and the covariance matrix for the reduced form errors is not diagonal unless the matrix $A$ is an identity matrix, which also means that none of the variables have a contemporaneous effects on each other.

To estimate the baseline model we employ a recursive VAR approach. The model suggest that both the fiscal deficit and the growth of money stock have a contemporaneous influence on the domestic inflation dynamics. However, our model also imply that inflation does not have a contemporaneous effect on either the 
government expenditure, fiscal deficit or the money stock. Therefore, we implement the following ordering in our VAR model: $r g$ (gov-t spending) $\rightarrow d$ (fiscal deficit) $\rightarrow$ $m 2$ (money stock) $\rightarrow \pi$ (inflation rate), denoting the causal impact running from the left to the right. Using $e_{t}$ and $u_{t}$ to denote the structural and reduced form shocks, respectively, the equation $A u_{t}=e_{t}$ takes the form:

$$
\left[\begin{array}{cccc}
a 11 & 0 & 0 & 0 \\
a 21 & a 22 & 0 & 0 \\
a 31 & a 32 & a 33 & 0 \\
a 41 & a 42 & a 43 & a 44
\end{array}\right]\left[\begin{array}{c}
u_{t}^{r g} \\
u_{t}^{b d} \\
u_{t}^{m 2} \\
u_{t}^{\pi}
\end{array}\right]=\left[\begin{array}{c}
e_{t}^{r g} \\
e_{t}^{b d} \\
e_{t}^{m 2} \\
e_{t}^{\pi}
\end{array}\right]
$$

which implies that shocks to inflation are not allowed to affect current values of the government spending, fiscal deficit or the money stock, but shocks to the government expenditure are allowed to affect current values of the inflation rate. Note that we do not impose any restrictions on the contemporaneous relationship between the growth rate of government spending, the fiscal deficit, and the money supply growth rate.

\subsection{Data}

Figure 1 and Figure 2 present time series plots of the four macroeconomic variables for Kazakhstan's economy: growth rate of government spending $(g)$, the official fiscal deficit as as share of GDP $(d)$, the money stock $(M 2)$ growth rate, and the inflation rate $(\pi)$. The frequency of all data is quarterly, and the time frame is from the first quarter of 2005 to the first quarter of 2020. The starting point was restricted due to concerns regarding both the quality and availability of the fiscal data. In addition, the period of the study reflects the paradigm shift in the macroeconomic policy, when Kazakhstan has started the exploitation phase of its rich oil fields. We use the seasonally adjusted data (X-12 procedure). Next, we outline the construction of the four variables in our VAR model and study the unit root tests on these variables. 
Figure 1: Government Spending and Fiscal Deficit in Kazakhstan
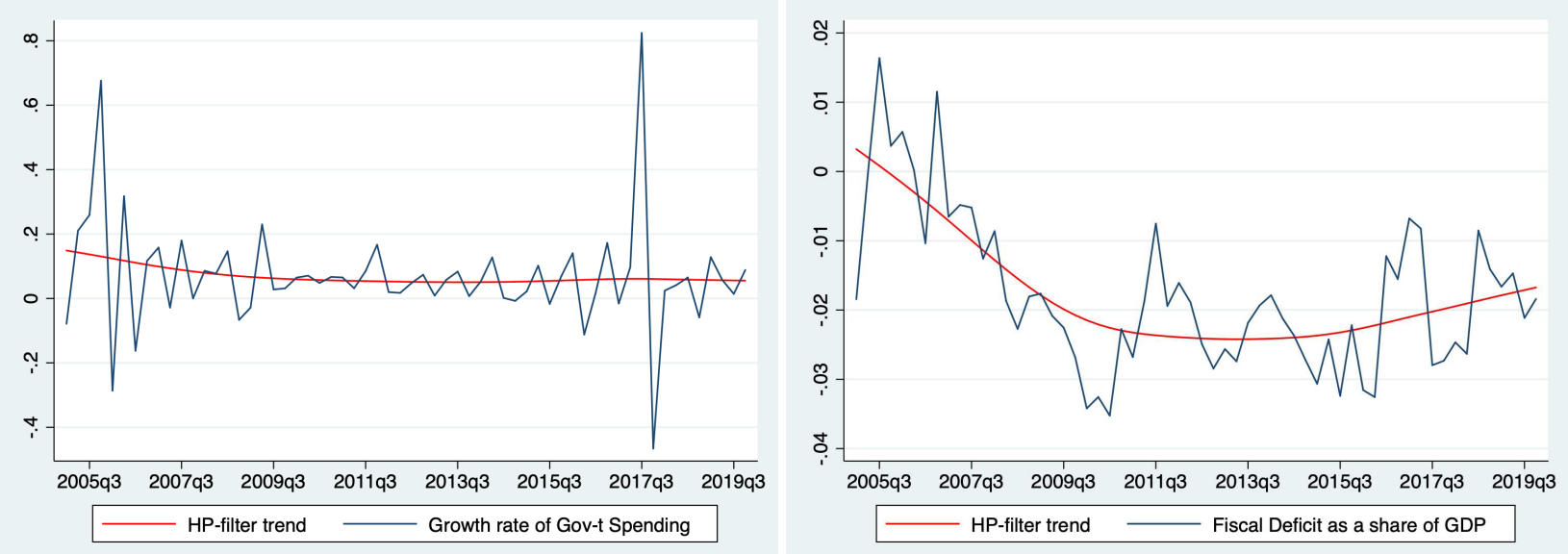

(a) Time series plots (with HP filter trend) of Gov-t Spending \& Fiscal Deficit, 2005Q1-2020Q1

Figure 2: Money Stock and Inflation in Kazakhstan
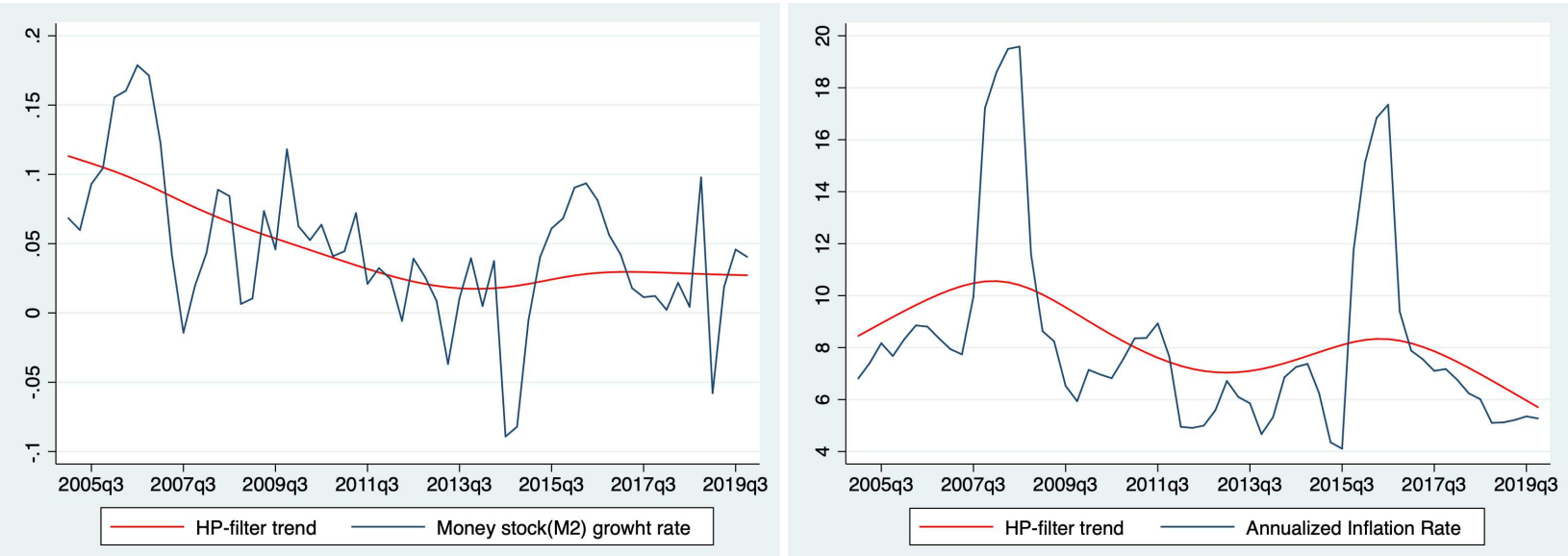

(a) Time series plots (with HP filter trend) of Money Stock \& Inflation Rate, 2005Q1-2020Q1

The variable on the aggregate government spending $(g)$ is obtained from the Ministry of Finance of Kazakhstan statistical bulletin. In addition, we derive two linked components, such as social spendings $\left(g_{s}\right)$ and manufacturing spending $\left(g_{i}\right)$, which we refer as "current consumption" and "investment consumption" by the government, respectively. We take the quarterly growth rate (Q-Q\%) of all forms of government spending. The original data series are recorded in the domestic currency, tenge. The fiscal deficit $(d)$ is estimated as a share of the given year's reported fiscal deficit relative to GDP, both registered in local currency. The series are taken from the Ministry of Finance statistical bulletin. The money stock $(m 2)$ is derived from the National Bank of Kazakhstan, and we report the quarterly growth rate of the parameter. Similarly, we document the annualized growth rate of the inflation rate 
of the domestic currency $(\pi)$. In addition to the observed data points, we plot the HP-filter trend to adjust for cyclical trends. A summary of all data description is concluded in the Table 1.

As a next step in our empirical investigation we perform an augmented Dickey-Fuller $(\mathrm{ADF})$ test to check for the presence of a unit root. We specify the test to allow for the drift term but not a time trend. The null hypothesis for the ADF test is that the time series has a unit root. We are able to reject the null for $g\left(g_{s}, g_{i}\right), d, m 2$ and $\pi$ at the $5 \%$ significance level. In particular, the ADF test rejects the null of non-stationarity for $g\left(g_{s}, g_{i}\right), d$, and $m 2$ at $1 \%$ level, and for $\pi$ at $5 \%$ level of significance. We therefore conclude that the time series $(g, d, m 2, \pi)$ are stationary. We use the lag length of 3 quarters, which is the optimal lag length as suggested by the Akaike information criterion (AIC).

\section{Results}

Dynamic interactions among the variables in the VAR model can be studied using impulse response functions (IRF), which trace out the time path of each variable to a one-unit one-time increase (shock) to the relevant VAR error. The IRF fits well for our purposes as it allows us to evaluate the presence of cyclical interactions among the variables in the VAR system. In particular, fluctuating responses of the variable around the zero line provides evidence of cyclical component movement in the given variable.

The impulse response functions generated using the structural shocks are presented in the Figure 3, Figure 4 and Figure 5 with $95 \%$ asymptotic confidence intervals. Figure 3 shows the impulse responses for all four variables due to a 1-standard deviation increase to the structural error associated with the aggregate government expenditure. A positive 1-st.deviation increase in the structural error associated with the fiscal spending produces a certain upward trend response in the inflation rate for the following 4 quarters, which also stays at that elevated level till the quarter 8. This pattern suggests, that a fiscal stimulus evidently generates a short-run inflationary pressure in the context of a small open economy. The cumulative effect during four quarters run ups to approximately $1 \%$ of additional inflation. Figure 4 and Figure 5 show IRFs due to a similar 1-st. deviation increase in social spending and manufacturing spending, respectively. The inflation effect of a shock to the social spending is weaker compared to the previous result, but nevertheless, produces a 
similar pattern of attaining the maximum effect around the fourth quarter and then remaining at that higher level. At the same time, a positive 1-standard deviation shock to manufacturing spending generates a small upward effect in the inflation rate, which also gradually subsides in the following 3 quarters, practically reversing the previous increase. Taken together, our results indicate that government spending shocks produce certain long-lasting inflationary impact. Particularly, manufacturing spending has a transitory and short-term effect, while social spending adds to a general aggregate government inflationary impact.

Moreover, Table 2, Table 3 and Table 4 provide results of the forecast error variance decomposition for a 10-quarter forecast horizon for each type of government spending separately. The forecast error variance decomposition (FEVD) explains the proportion of the movements in a variable due to its own shock against shocks to other parameters in the specified VAR model. In other words, it measures the relative weight of each structural shock for the explanation of the total variance of each variable Table 2 suggests that, a considerable proportion of the variation in the inflation rate is accounted for by the shocks to the given fiscal variables: fiscal deficit (29\%) and government spending (11\%) as the forecast horizon reaches 10 lags. Similar dynamics are reproduced in the FEVDs using the Social Spending and Investment Spending, respectively (Table 3 and Table 4 ).

Figure 3: Impact of a 1-st.deviation shock to the Government Spending

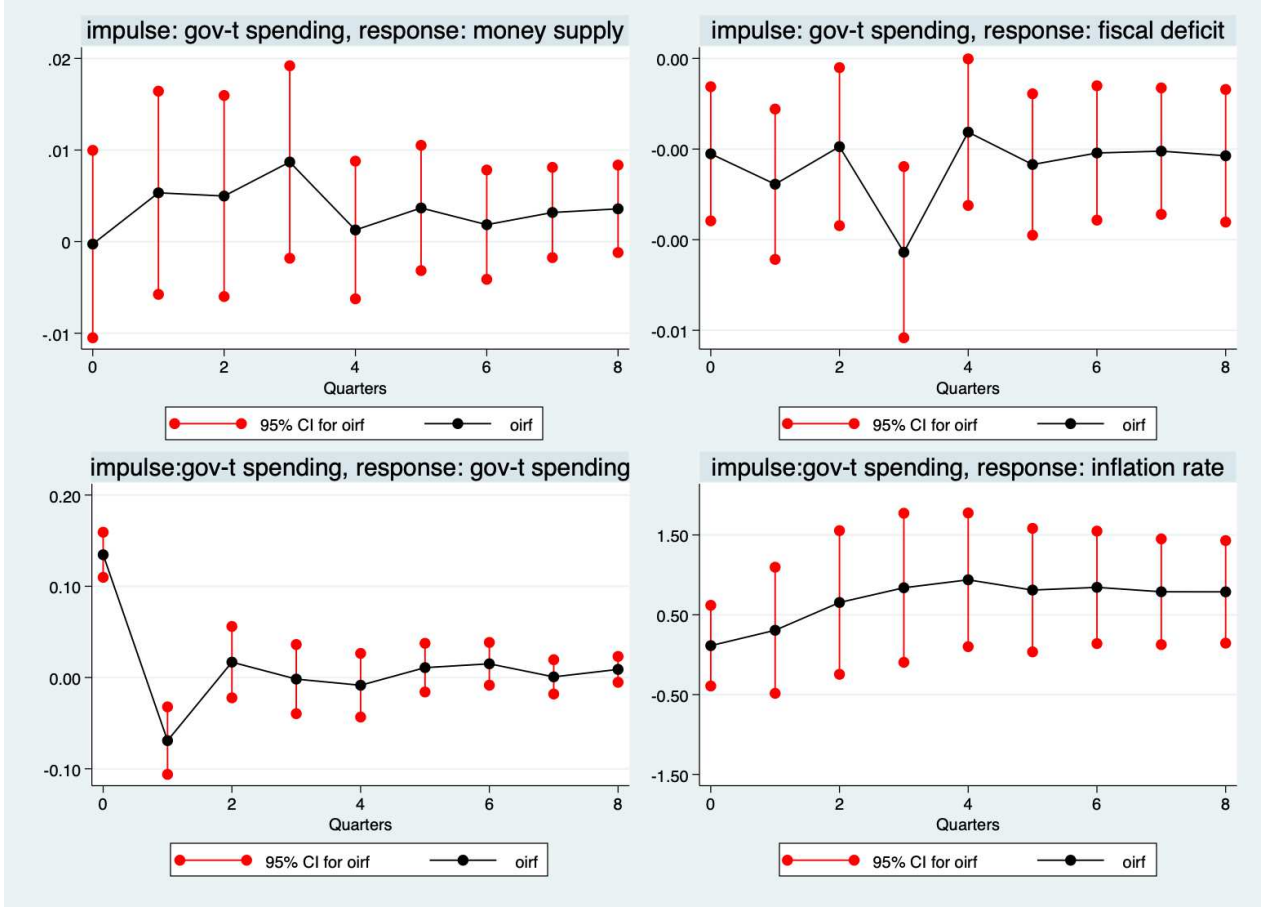


Figure 4: Impact of a 1-st.deviation shock to the Social Spending
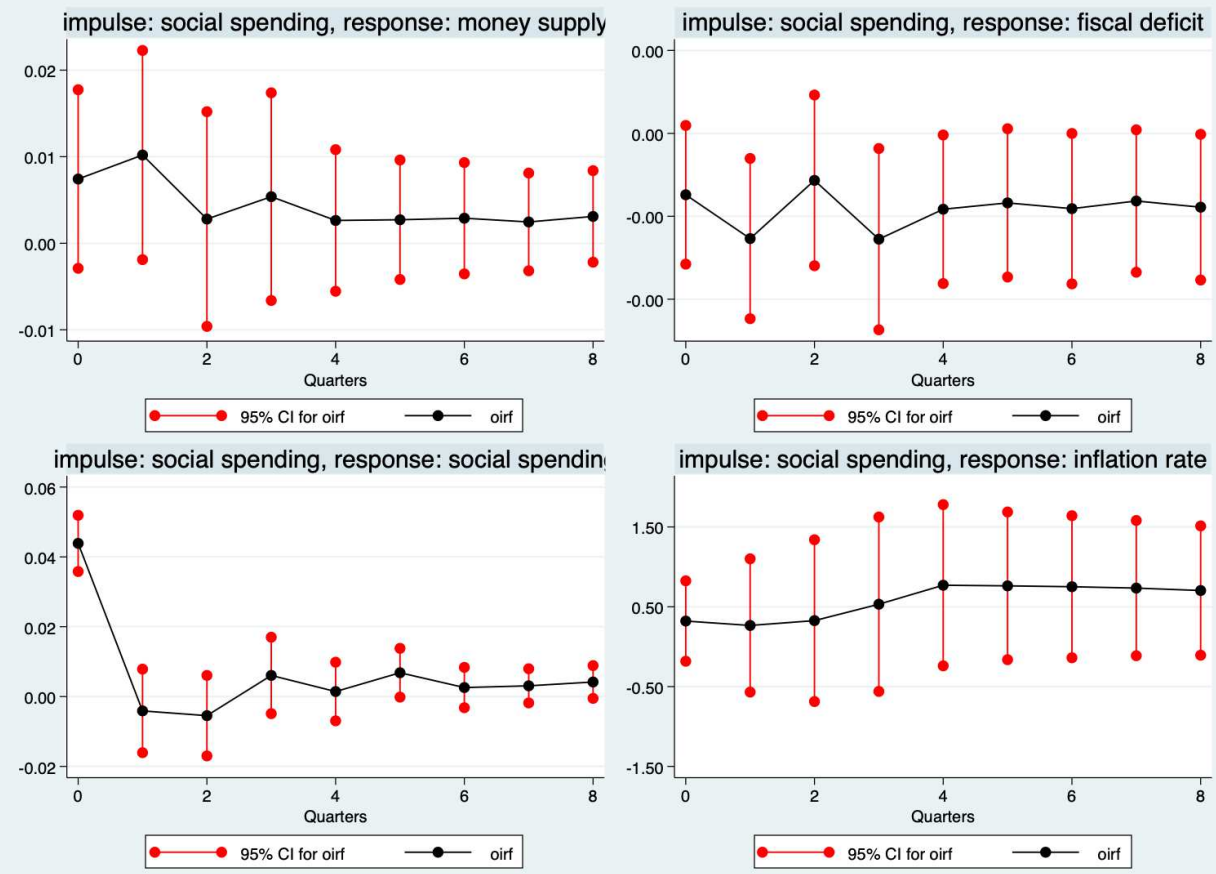

Figure 5: Impact of a 1-st.deviation shock to the Manufacturing Spending
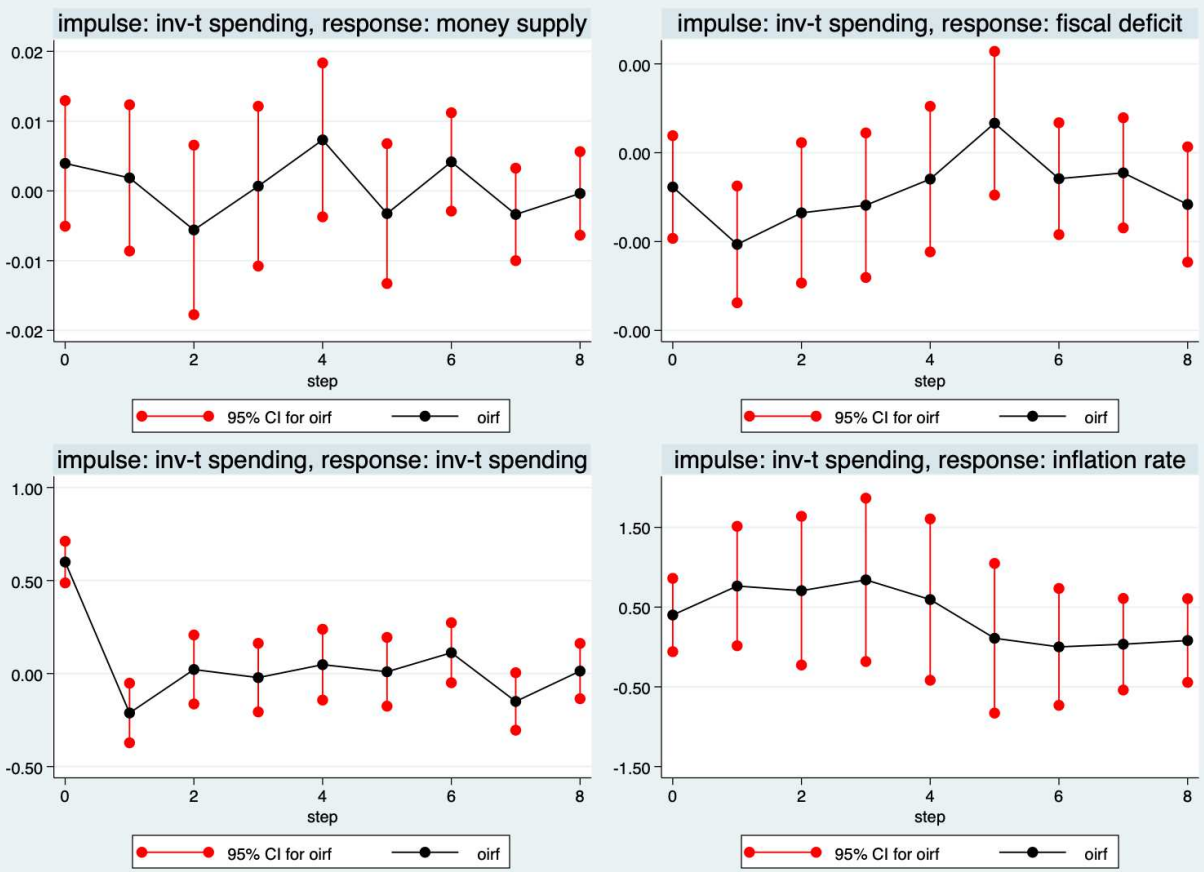

(a) Impulse Response Functions (with 95\% CI) from a 4-variable VAR of Kazakhstan's economy for the period 2005Q1-2020Q1 


\section{Discussion}

As it is evident from the Figure 6 and Figure 7, "Social Protection" spending accounts for about a third of all public spending in Kazakhstan and has been steadily growing over the last five years. A heavy cash-based social orientation of state budget expenditures may lead to a long-term structural reduction in aggregate demand (determining the upper limit of consumption of certain groups of the population), and at the same time, has a potential to suppress investment and productivity in industrial sectors of the economy (a decrease in capital-intensive and export-oriented industries) Parui (2020). As a consequence, such a pro-subsidy fiscal policy can lead to an increase in service-oriented sectors, reduction in the supply of goods, and an acceleration of money turnover, which entails an increase in pro-inflationary pressures in the medium term.

Figure 6: Public Spending Allocation by Sectors in Kazakhstan, 2019

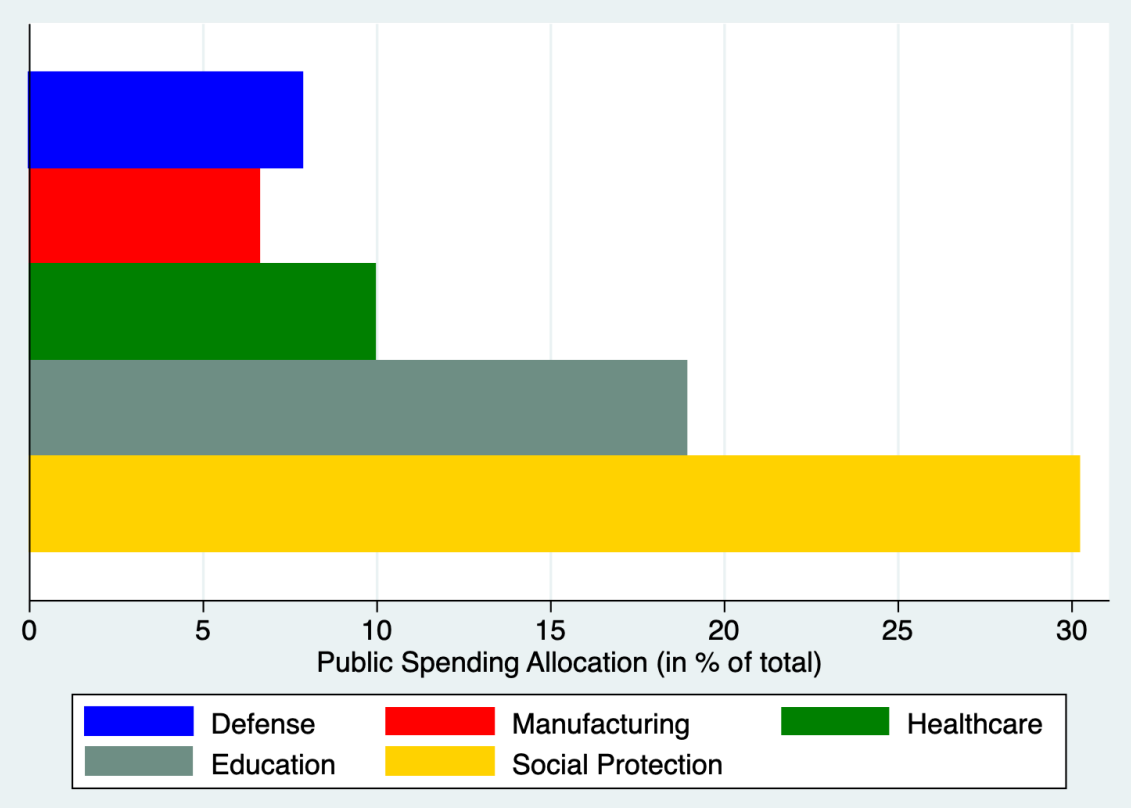

Source: Eurasian Economic Commission 
Figure 7: Public Spending Allocation by Sectors in Kazakhstan, 2013-2019

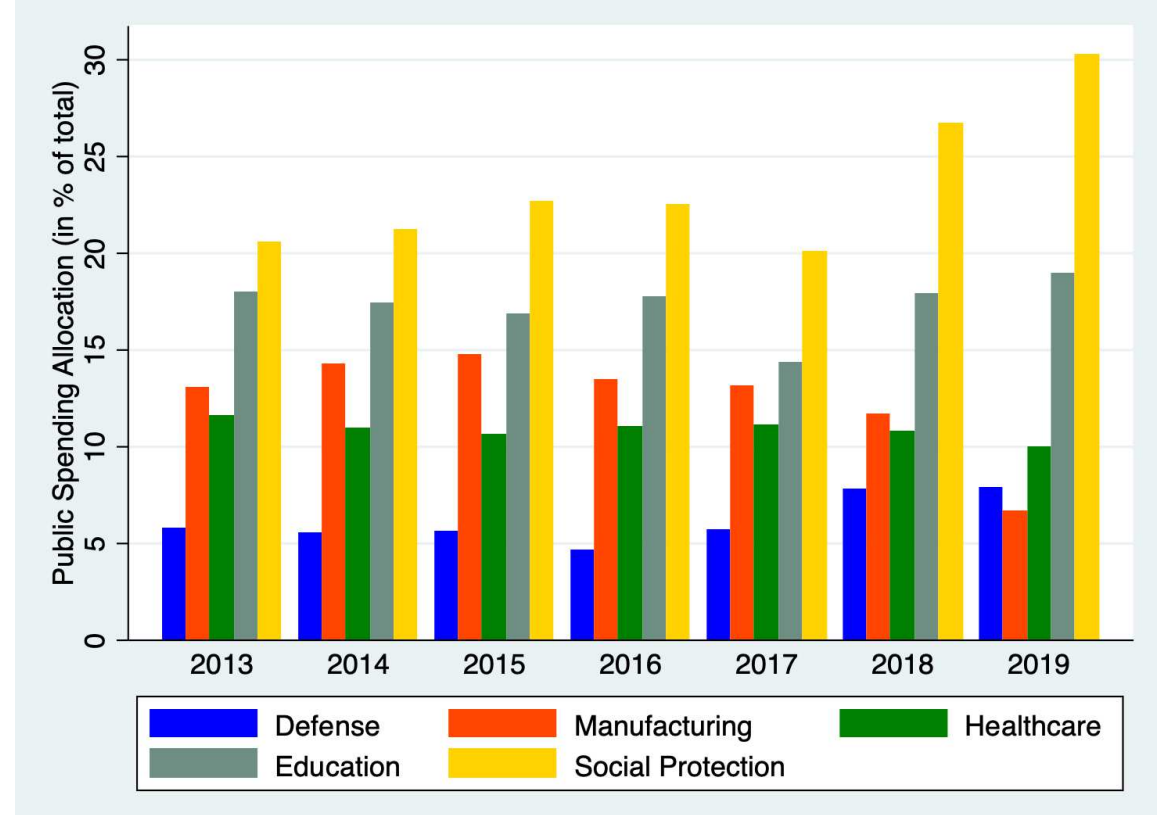

Source: Eurasian Economic Commission

In Kazakhstan, targeted social assistance (henceforth - TSA) has been assigned since 2002. As of 2020, in order to receive TSA, it is necessary that the average per capita income for each family member does not exceed $70 \%$ of the subsistence level. This led to the expansion of the coverage of the population with targeted social assistance. Thus, the number of people receiving TSA has almost quadrupled and exceeded 2 million people in 2019. TSA payments for the adult population are calculated as the difference between the average per capita household income and the poverty line. Since 2019, TSA for minor children in low-income families began to be paid in the amount of $70 \%$ of the subsistence minimum, and not the difference between the average per capita income, so the average monthly amount of benefits in the republic on average increased by more than 2.5 times and amounted to 12,188 tenge ( $\$ 29.01$, by January 2021 exchange rates). Recently, there was also an increase in the share of those who received TSA in major cities. In particular, in 2019, 16.7\% of all TSA recipients lived in Almaty, Nur-Sultan, Shymkent, which increased to $25.1 \%$ in 2020. This partially can be explained by a quarantine measures to tackle the Covid-19 spread and that majority of services sectors are concentrated in urban centers. 


\section{Conclusion}

In this paper we use a VAR model that aims to reflect the main patterns of Kazakhstan's economy to empirically investigate the impact of fiscal policy on the inflation rate. Kazakhstan's economy underwent a significant shift around the mid-2000s and the entire 2010s, as the country has experienced windfall of oil revenues that likely have caused a greater procyclical in the fiscal policy. Specifically, the paper distinguishes between social protection spending (current consumption), and public procurement, proxied by the manufacturing and industrial spending (capital consumption).

We collect a database of quarterly data for selected variables for the time period 2005Q1-2020Q1. As a result, we find that a fiscal policy shock have certain positive effects on the inflation rate. In particular, social protection spending adds $1 \%$ to the inflation rate in the following four quarters, while the government capital purchases do not produce sizable effect on inflation dynamics even in the longer term horizons. Overall, for the fiscal policy to become inflation-neutral, we suggest several policy recommendations.

The results overall support the view of Catao and Terrones (2005) and Lin and Chu (2013), that sustained fiscal deficits and excess government spending are inflationary in high and middle-inflation economies and is less inflationary in low-inflation economies. Therefore, for the fiscal policy to become inflation-neutral and to facilitate a decrease in the domestic inflationary pressures, it should direct bulk of its government spending toward public manufacturing investment, stimulating employment creation rather than direct cash-based social transfers, which can only expand non-productive current government consumption. A shift in the social protection policy from subsidy-based to wage-aimed paradigm is evidently beneficial in the longer-term.

\section{Declarations}

\section{Availability of data}

Data available upon request from the authors

\section{Competing interests}

The authors declare that they have no competing interests

\section{Funding}

Not applicable 


\section{Authors' contributions}

The collection, processing and analysis of the data were carried out by the authors. All authors read and approved the final manuscript

\section{Acknowledgements}

Not applicable

Ethics approval and consent to participate

Not applicable

Consent for publication

Not applicable

\section{References}

A. Alesina and A. Drazen. Why are stabilizations delayed? Technical report, National Bureau of Economic Research, 1989.

S. W. Barnhart and A. F. Darrat. Budget deficits, money growth and causality: Further oecd evidence. Journal of International Money and Finance, 7(2):231-242, 1988.

E. Benmelech and N. Tzur-Ilan. The determinants of fiscal and monetary policies during the covid-19 crisis. NBER Working Paper, (w27461), 2020.

W. H. Buiter. The fiscal theory of the price level: A critique. The Economic Journal, 112(481):459-480, 2002.

G. A. Calvo and C. A. Végh. Inflation stabilization and bop crises in developing countries. Handbook of macroeconomics, 1:1531-1614, 1999.

M. B. Canzoneri, R. E. Cumby, and B. T. Diba. Is the price level determined by the needs of fiscal solvency? American Economic Review, 91(5):1221-1238, 2001.

L. A. Catao and M. E. Terrones. Fiscal deficits and inflation. Journal of Monetary Economics, 52(3):529-554, 2005.

R. W. Click. Seigniorage in a cross-section of countries. Journal of Money, Credit and Banking, pages 154-171, 1998.

J. H. Cochrane. A frictionless view of us inflation. NBER macroeconomics annual, 13: 323-384, 1998.

J. H. Cochrane. Long-term debt and optimal policy in the fiscal theory of the price level. Econometrica, 69(1):69-116, 2001. 
J. H. Cochrane. Money as stock. Journal of Monetary Economics, 52(3):501-528, 2005.

C. Cottarelli, M. E. Griffiths, and R. Moghadam. The nonmonetary determinants of inflation: A panel data study. 1998.

J. De Haan and D. Zelhorst. The impact of government deficits on money growth in developing countries. Journal of International Money and Finance, 9(4):455-469, 1990.

I. Domaç and E. M. Yücel. What triggers inflation in emerging market economies? Review of world economics, 141(1):141-164, 2005.

D. W. Elmendorf and N. G. Mankiw. Government debt. Handbook of macroeconomics, 1:1615-1669, 1999.

G. Epstein. The empirical and institutional limits of modern money theory. Review of Radical Political Economics, page 0486613420912464, 2020.

S. Fischer, R. Sahay, and C. A. Végh. Modern hyper-and high inflations. Journal of Economic literature, 40(3):837-880, 2002.

D. S. Giannaros and B. R. Kolluri. Deficit spending, money, and inflation: Some international empirical evidence. Journal of Macroeconomics, 7(3):401-417, 1985.

G. Kwon, L. McFarlane, and W. Robinson. Public debt, money supply, and inflation: a cross-country study. IMF Staff Papers, 56(3):476-515, 2009.

E. M. Leeper. Equilibria under 'active'and 'passive'monetary and fiscal policies. Journal of monetary Economics, 27(1):129-147, 1991.

E. M. Leeper and T. Yun. Monetary-fiscal policy interactions and the price level: Background and beyond. International Tax and Public Finance, 13(4):373-409, 2006.

H.-Y. Lin and H.-P. Chu. Are fiscal deficits inflationary? Journal of International Money and Finance, 32:214-233, 2013.

N. V. Loayza and S. Pennings. Macroeconomic policy in the time of covid-19: A primer for developing countries, 2020.

P. Loungani and P. Swagel. Sources of inflation in developing countries. 2001.

K. Metin. The relationship between inflation and the budget deficit in turkey. Journal of Business \& Economic Statistics, 16(4):412-422, 1998. 
P. Parui. Government expenditure and economic growth: a post-keynesian analysis. International Review of Applied Economics, pages 1-29, 2020.

A. A. Protopapadakis and J. J. Siegel. Are money growth and inflation related to government deficits? evidence from ten industrialized economies. Journal of International Money and Finance, 6(1):31-48, 1987.

T. J. Sargent, N. Wallace, et al. Some unpleasant monetarist arithmetic. Federal reserve bank of minneapolis quarterly review, 5(3):1-17, 1981.

C. A. Sims. Macroeconomics and reality. Econometrica: journal of the Econometric Society, pages 1-48, 1980.

C. A. Sims. A simple model for study of the determination of the price level and the interaction of monetary and fiscal policy. Economic theory, 4(3):381-399, 1994.

T. Stubbs, W. Kring, C. Laskaridis, A. Kentikelenis, and K. Gallagher. Whatever it takes? the global financial safety net, covid-19, and developing countries. World Development, 137:105171, 2020.

M. Woodford. Monetary policy and price level determinacy in a cash-in-advance economy. Economic theory, 4(3):345-380, 1994.

M. Woodford. Price-level determinacy without control of a monetary aggregate. In Carnegie-Rochester conference series on public policy, volume 43, pages 1-46. Elsevier, 1995.

M. Woodford. Fiscal requirements for price stability. Technical report, National Bureau of Economic Research, 2001. 


\section{Appendix}

Table 1: Variables Description

\begin{tabular}{|c|c|c|}
\hline Variable & Description & Source \\
\hline $\begin{array}{c}\text { a) Government Spending } \\
\text { b) Social Gov-t Spending } \\
\text { c) Investment Spending }\end{array}$ & Growth Rate (\%) & Ministry of Finance of Kazakhstan \\
& Growth Rate (\%) & Ministry of Finance of Kazakhstan \\
\hline Fiscal Deficit & Showth Rate (\%) & Ministry of Finance of Kazakhstan \\
\hline Money Stock & Growth Rate of $M 2(\%)$ & National Bank of Kazakhstan \\
\hline Inflation Rate & Annualized Growth Rate (YoY\%) & National Bank of Kazakhstan \\
\hline
\end{tabular}

(a) The dataset was collected manually from the Statistical Bulletin of the Ministry of Finance.The data from the National Bank of Kazakhstan was downloaded from the Central Bank's official website.

Table 2: Forecast Error Variance Decomposition: Government Spending

\begin{tabular}{lllll}
\hline & Inflation Rate & Deficit & M2 & Gov-t Spending \\
\hline 1 & 0.003364 & 0.127548 & 0.000047 & 1 \\
2 & 0.010482 & 0.232105 & 0.013074 & 0.858049 \\
3 & 0.034001 & 0.243402 & 0.020657 & 0.823641 \\
4 & 0.062262 & 0.378768 & 0.045861 & 0.798783 \\
5 & 0.091915 & 0.376883 & 0.044561 & 0.791591 \\
6 & 0.109045 & 0.395599 & 0.048122 & 0.788705 \\
7 & 0.12679 & 0.398717 & 0.048174 & 0.785769 \\
8 & 0.140208 & 0.402321 & 0.050558 & 0.783467 \\
9 & 0.152975 & 0.406672 & 0.053754 & 0.783546 \\
10 & 0.164762 & 0.413471 & 0.058137 & 0.781834 \\
\hline
\end{tabular}

(a) The results reported are for the benchmark VAR model with 3 lags, and the entries in the table give percentage of the forecast error variance that is explained by each of the four variables in each column. The forecast horizons ranges from 1 to 10 quarters. 
Table 3: Forecast Error Variance Decomposition: Social Spending

\begin{tabular}{lllll}
\hline & Inflation Rate & Deficit & M2 & Social Spending \\
\hline 1 & 0.027008 & 0.051514 & 0.034273 & 1 \\
2 & 0.01627 & 0.139047 & 0.067662 & 0.847983 \\
3 & 0.016617 & 0.127045 & 0.058917 & 0.738005 \\
4 & 0.026056 & 0.167488 & 0.06429 & 0.711178 \\
5 & 0.045019 & 0.178629 & 0.062972 & 0.689588 \\
6 & 0.059409 & 0.17926 & 0.06293 & 0.678628 \\
7 & 0.071095 & 0.185325 & 0.063332 & 0.66334 \\
8 & 0.080852 & 0.186737 & 0.063439 & 0.650231 \\
9 & 0.088718 & 0.190612 & 0.064725 & 0.641377 \\
10 & 0.095261 & 0.192917 & 0.065911 & 0.632431 \\
\hline
\end{tabular}

(a) The results reported are for the benchmark VAR model with 3 lags, and the entries in the table give percentage of the forecast error variance that is explained by each of the four variables in each column. The forecast horizons ranges from 1 to 10 quarters.

Table 4: Forecast Error Variance Decomposition: Investment Spending

\begin{tabular}{lllll}
\hline & Inflation Rate & Deficit & M2 & Inv-t Spending \\
\hline 1 & 0.072479 & 0.075042 & 0.046017 & 1 \\
2 & 0.104323 & 0.106186 & 0.039541 & 0.968068 \\
3 & 0.08613 & 0.097772 & 0.042937 & 0.76986 \\
4 & 0.088112 & 0.126382 & 0.039868 & 0.683268 \\
5 & 0.094716 & 0.137178 & 0.038495 & 0.678138 \\
6 & 0.098087 & 0.144241 & 0.040765 & 0.680231 \\
7 & 0.098648 & 0.147032 & 0.041887 & 0.671705 \\
8 & 0.097469 & 0.148638 & 0.041711 & 0.66392 \\
9 & 0.097018 & 0.151832 & 0.041358 & 0.657589 \\
10 & 0.097802 & 0.154768 & 0.041594 & 0.654092 \\
\hline
\end{tabular}

(a) The results reported are for the benchmark VAR model with 3 lags, and the entries in the table give percentage of the forecast error variance that is explained by each of the four variables in each column. The forecast horizons ranges from 1 to 10 quarters. 
Figures
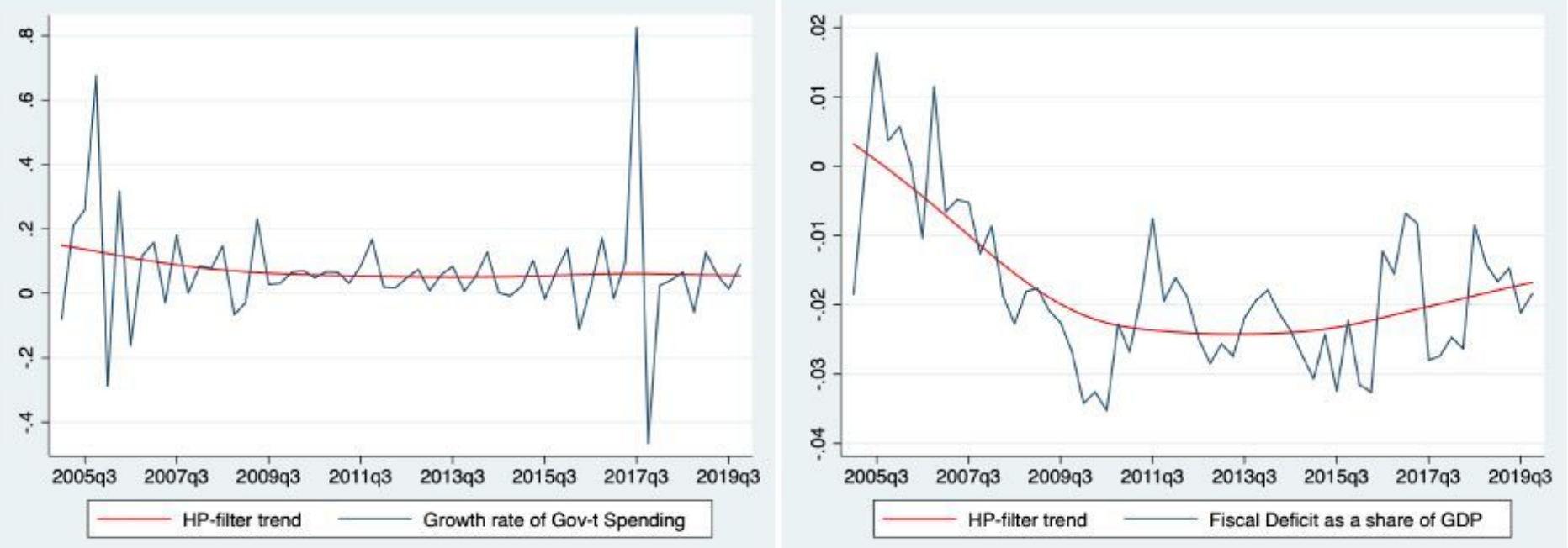

(a) Time series plots (with HP filter trend) of Gov-t Spending \& Fiscal Deficit, 2005Q1-2020Q1

\section{Figure 1}

Government Spending and Fiscal Deficit in Kazakhstan
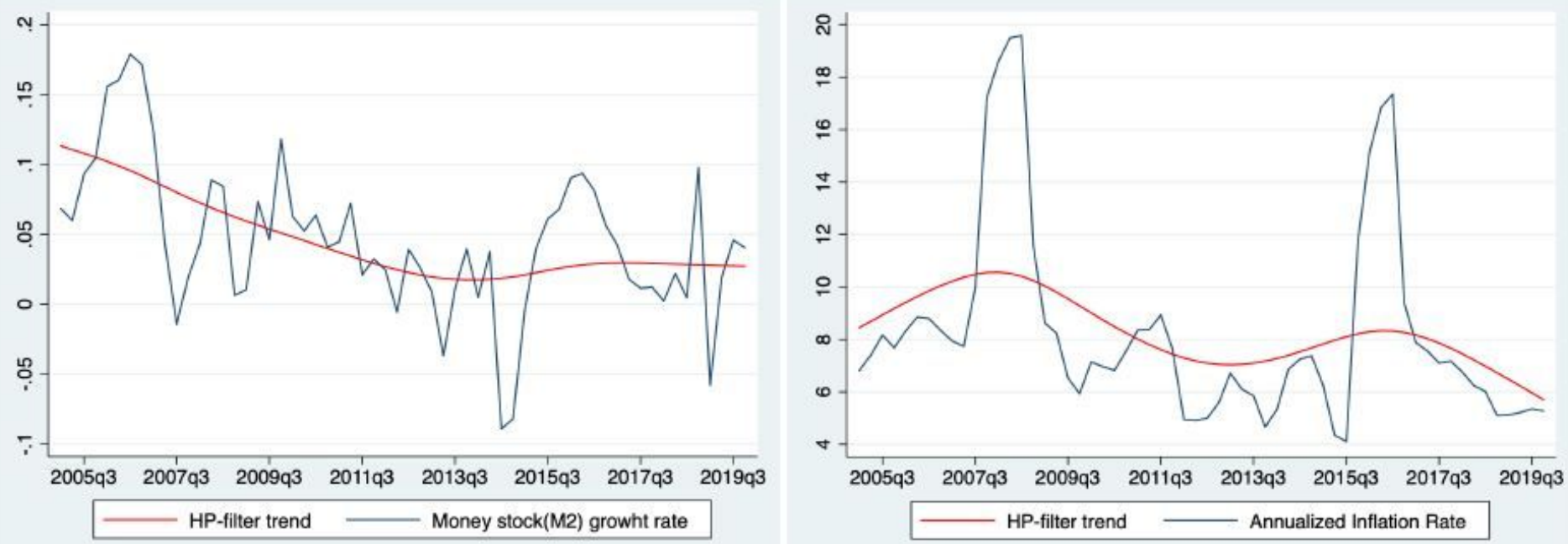

(a) Time series plots (with HP filter trend) of Money Stock \& Inflation Rate, 2005Q1-2020Q1

\section{Figure 2}

Money Stock and Inflation in Kazakhstan 

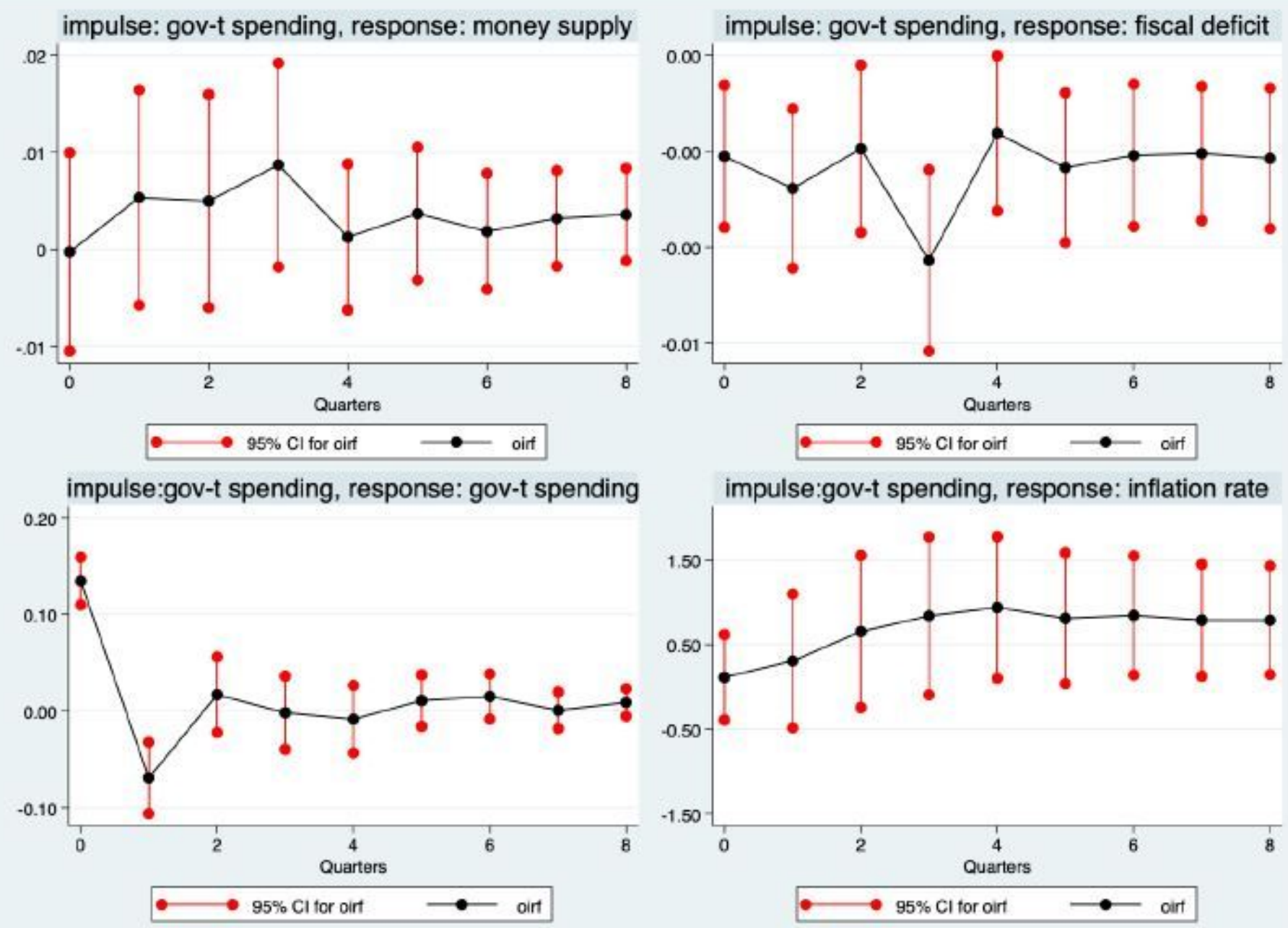

\section{Figure 3}

Impact of a 1-st.deviation shock to the Government Spending 

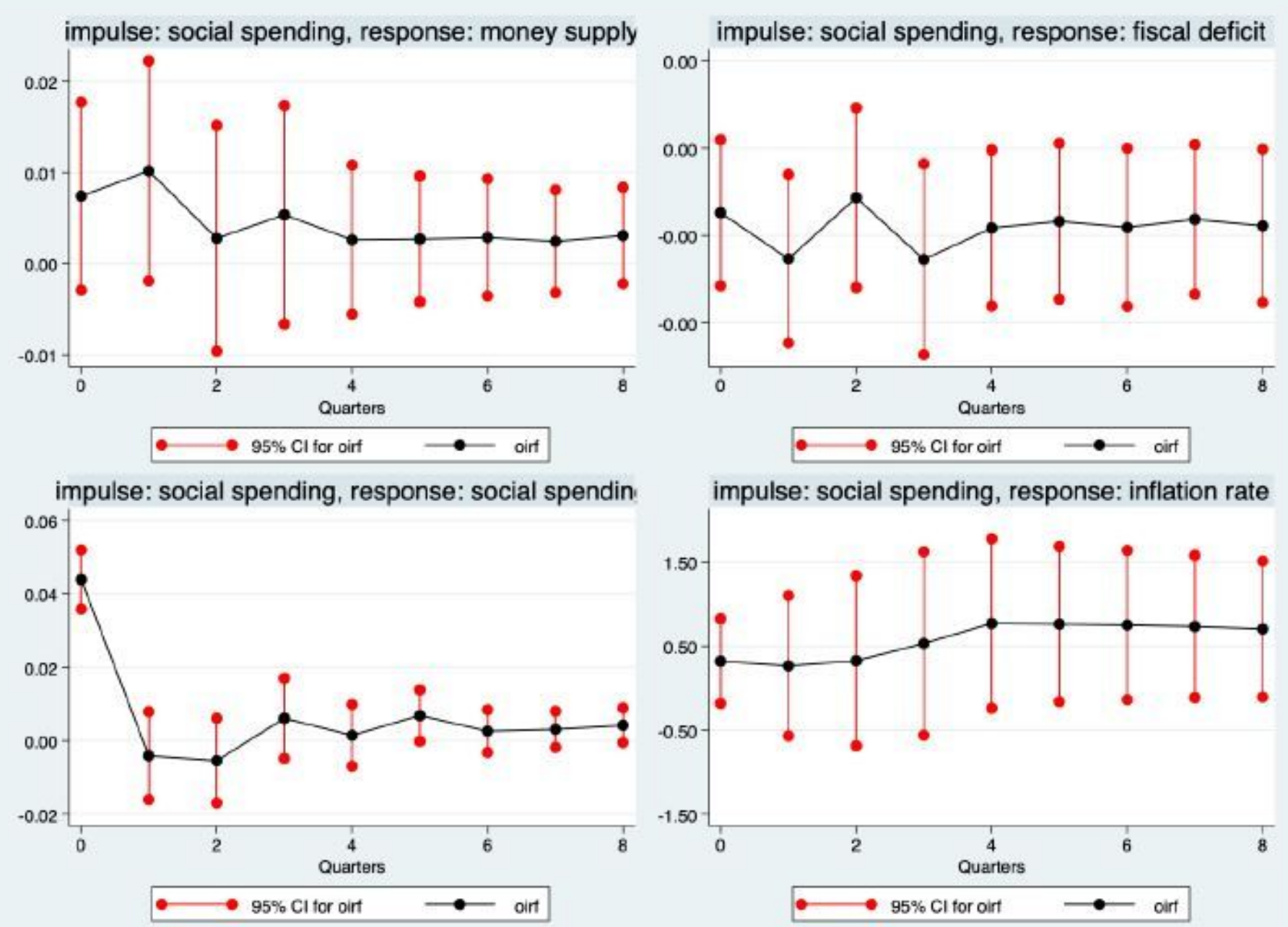

Figure 4

Impact of a 1-st.deviation shock to the Social Spending 

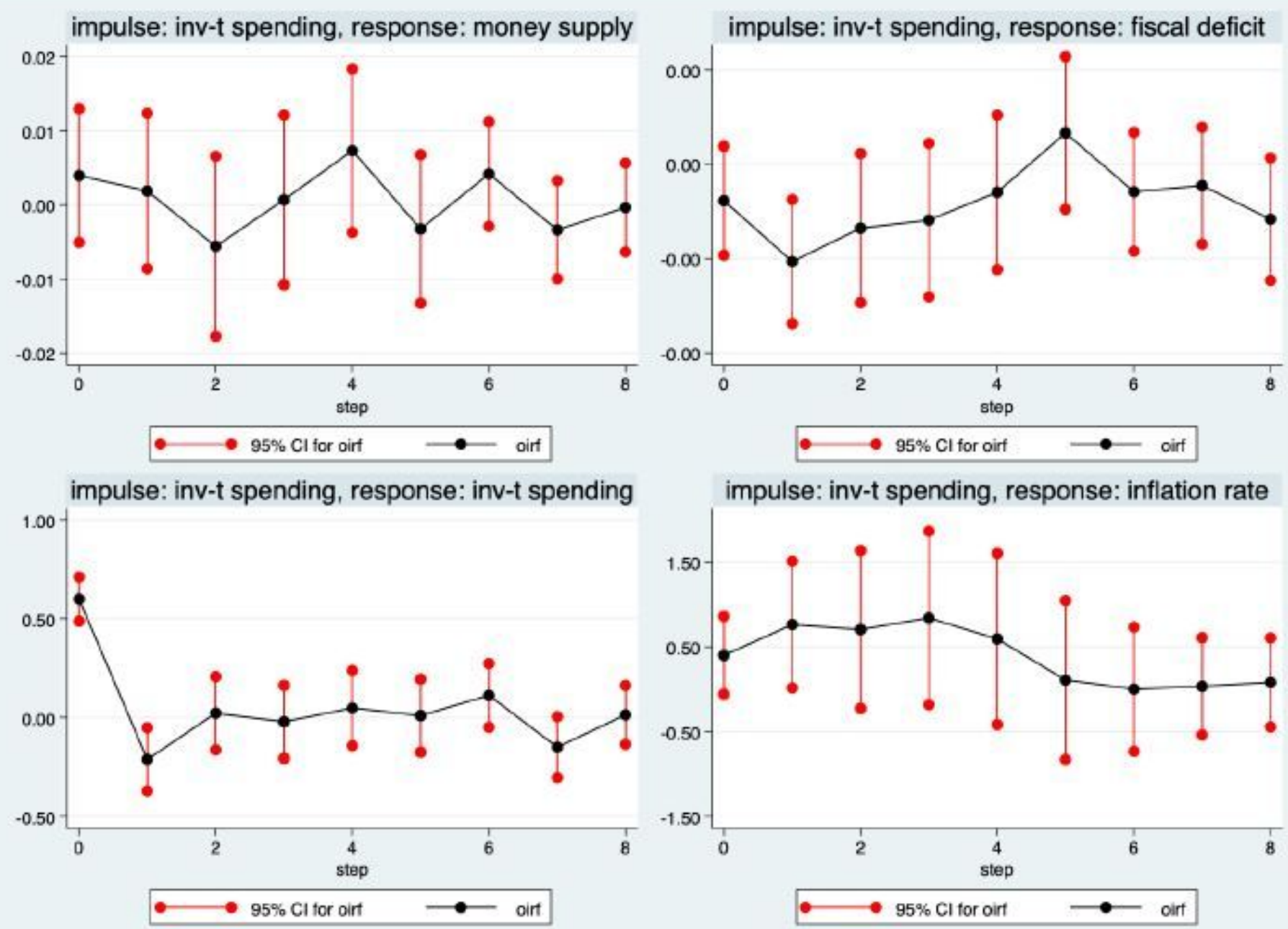

(a) Impulse Response Functions (with 95\% CI) from a 4-variable VAR of Kazakhstan's economy for the period 2005Q1-2020Q1

Figure 5

Impact of a 1-st.deviation shock to the Manufacturing Spending 


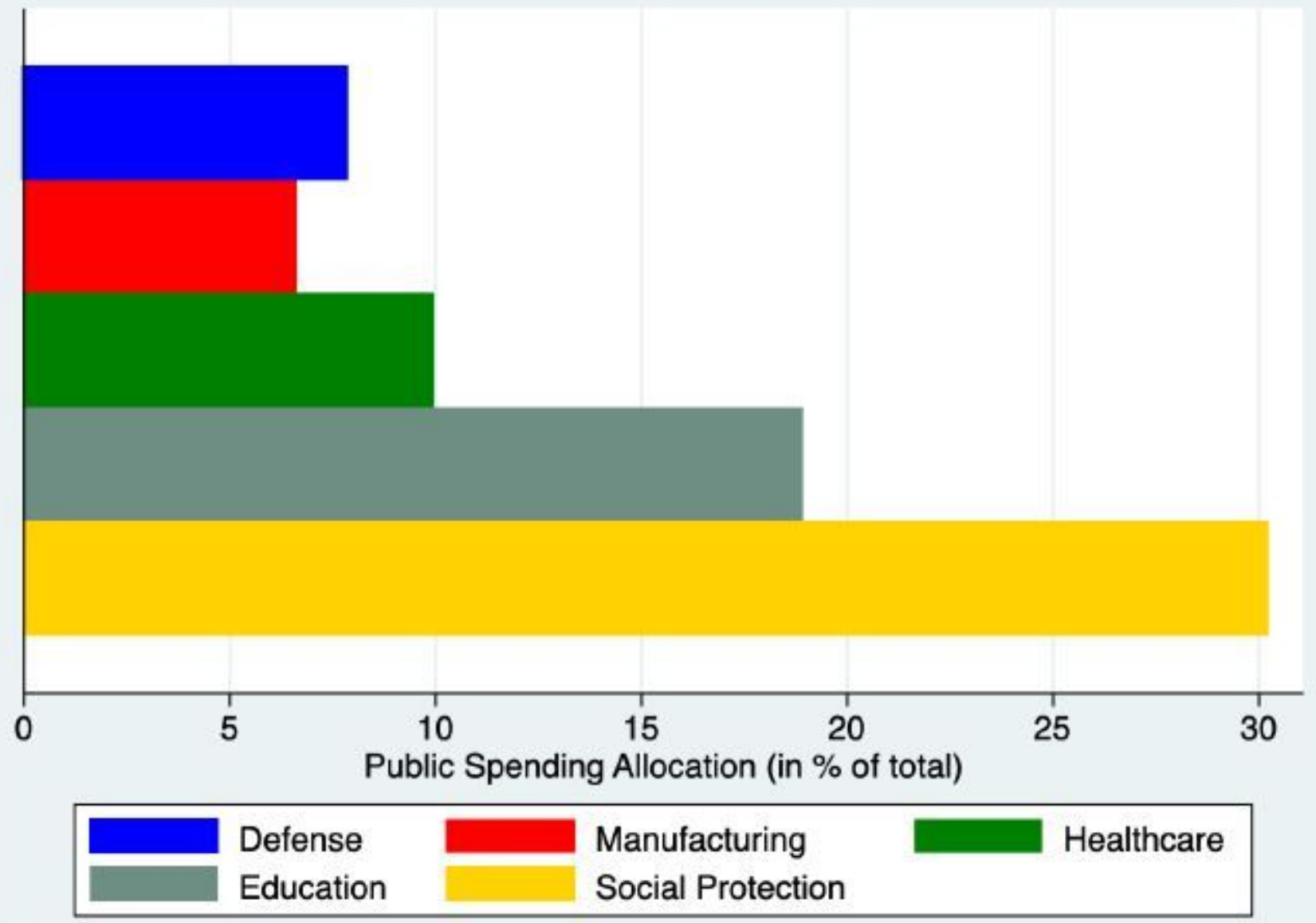

Source: Eurasian Economic Commission

Figure 6

Public Spending Allocation by Sectors in Kazakhstan, 2019 


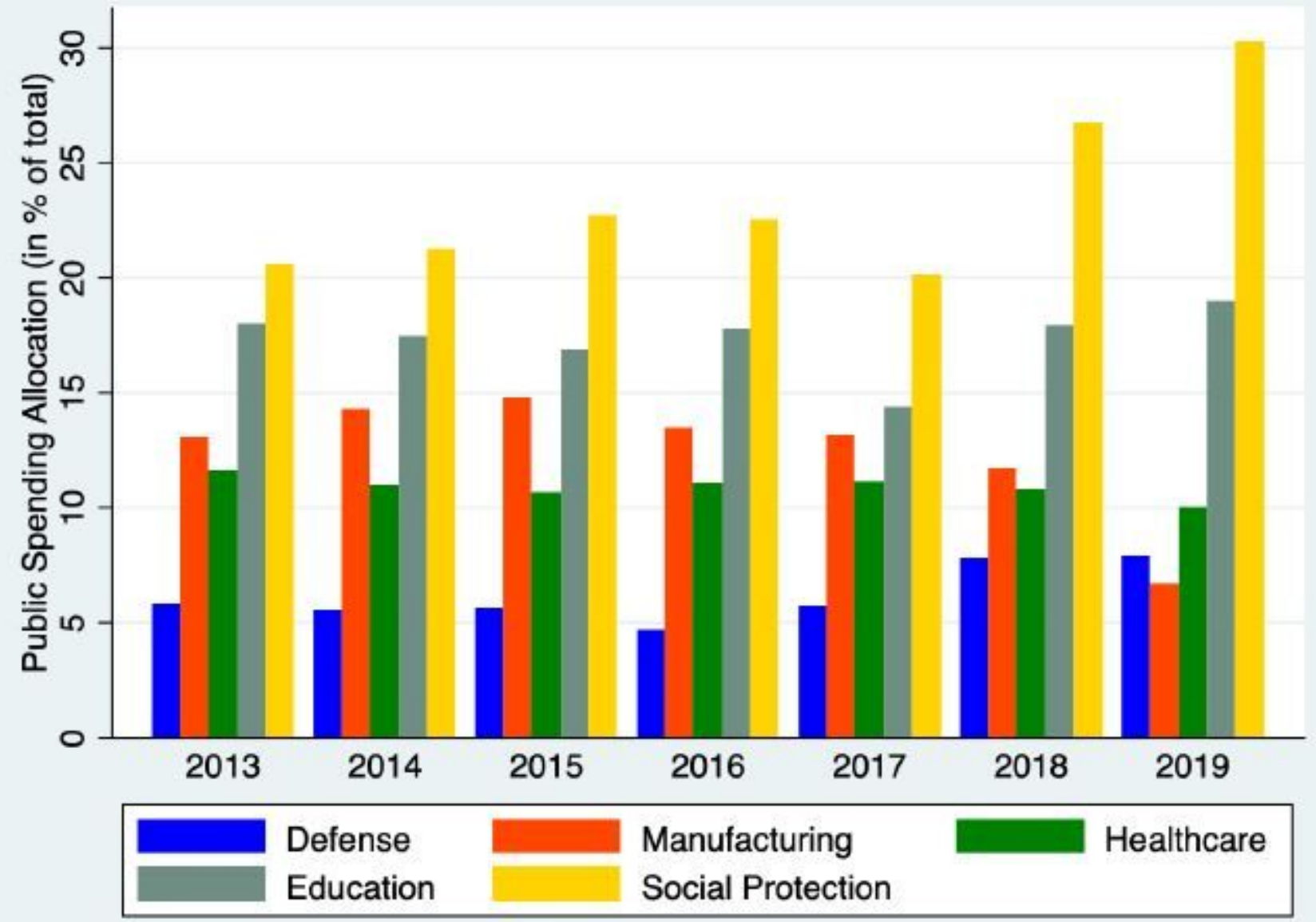

Source: Eurasian Economic Commission

Figure 7

Public Spending Allocation by Sectors in Kazakhstan, 2013-2019 